\title{
Plea Bargaining Changing Nordic Criminal Procedure: Sweden and Finland as Examples
}

\author{
Laura Ervo
}

\begin{abstract}
A plea bargaining system is a novelty and originally a legal transplant in Northern European countries. It exists - in some form-for instance in Finland, Norway and Denmark, whereas in Sweden only the system of crown witnesses is likely to be introduced. In this chapter plea bargaining is put into the East-NordicFinnish and Swedish — contexts. How does plea bargaining fit into the East-Nordic court culture? Which ingredients does the contemporary legal culture consist of? In which way is court culture changing due to the new values in the society? Or are the amendments made primarily to reduce the costs of the state? Fairness, procedural justice, conflict resolution, negotiated law, pragmatically acceptable compromise, procedural truth, court service, communication and interaction are examples of the topics that are currently discussed in Finland and Sweden. At the same time, the use of written proceedings and proceedings in the absence of an accused are increasing. Is the plea bargaining system a step towards a more effective and economic criminal procedural system or is it mirroring new type of thinking concerning criminal proceedings? In this chapter, these elements are discussed. Finland is used as a main example. The Finnish situation is also compared with Sweden.
\end{abstract}

\section{Starting Points}

Many Nordic and Baltic countries have recently adopted a plea-bargaining ${ }^{1}$ system. $^{2}$ It exists - in some form-in Finland, Estonia, Norway, Denmark, and Latvia. ${ }^{2}$ In Sweden, plea bargaining is not possible, but recently a discussion on crown witnesses,

\footnotetext{
${ }^{1}$ According to the Oxford English dictionary, plea bargaining refers to an arrangement between prosecutor and defendant whereby the defendant pleads guilty to a lesser charge in exchange for a more lenient sentence or an agreement to drop other charges.
}

${ }^{2}$ Ervo (2014a), pp. 97-98 and Oikarainen (2012), p. 752-753.

L. Ervo $(\varangle)$

School of Law, Psychology and Social Work, Örebro University, 70182 Örebro, Sweden

e-mail: Laura.ervo@oru.se 
as one variant of plea bargaining, ${ }^{3}$ has arisen. ${ }^{4}$ As a procedural instrument, plea bargaining is quite new in Northern Europe. How does it fit into our traditional court culture, or is the court culture no longer the same?

There are controversial trends in criminal proceedings. On the one hand, fairness, procedural justice, conflict resolution, negotiated law, pragmatically acceptable compromise, procedural truth, court service, communication, interaction, plea bargaining, and anonymous witnesses are good examples of the currently discussed topics. $^{5}$

Based on those new trends, the values in the criminal jurisdiction seem to be softening. The individual's rights are stressed. The parties are more subjects than objects in the investigation made at courts. The decision power is going to be taken from the judge to the court's clients. The service culture has landed in the public sector, including even the courts, which traditionally have been formal and power-packed institutions. From that perspective, criminal proceedings have recently become closer to civil proceedings. ${ }^{6}$

Still, there are at the same time trends in the opposite direction, which means efficiency in the name of economy. The written proceedings in simple and clear criminal cases as well as proceedings in the absence of an accused are good examples. The possibility of solving a criminal case in the absence of the accused is quite widespread both in Sweden ${ }^{7}$ and in Finland. ${ }^{8}$ The plea-bargaining system is also one step towards a more effective and economic criminal procedural system.

The development described above is rather confusing. What is going on in the Nordic criminal procedural law and why? Are these changes mirroring the current values in the society, and is the culture therefore changing $?^{9}$ Or are all these steps taken only to favour the treasury ministry and to intensify the state economy? Are there other practical needs, like the fight against organised crime, behind this change? Is it the development about privatisation, intensifying criminal proceedings, or is this change linked with the cultural change in mentalities? Does not the society share the same values any longer? Is also the way of thinking is changing?

Finland and Sweden are chosen as examples because the current situations of those neighboring countries vary quite dramatically in terms of the acceptance of plea bargaining. Finland has accepted and adopted plea bargaining into its criminal procedural system, while the discussion in Sweden has been rather unwelcoming. Still, the discussion on crown witnesses continues in Sweden. Because of this controversial situation between two East-Nordic countries which otherwise share quite

\footnotetext{
${ }^{3}$ Lauri (2010), p. 12.

${ }^{4}$ https://www.regeringen.se/pressmeddelanden/2019/11/en-starkt-rattsprocess-och-en-okad-lagfor ing/, accessed 28 June 2020.

${ }^{5}$ See, e.g., Ervo (2014a), p. 99 and Määttä (2013), p. 647.

${ }^{6}$ Määttä (2013), p. 647.

${ }^{7}$ The Swedish Code for Juridical Procedure, Chap. 46, Sect. 15 a.

${ }^{8}$ Chap. 8, Sects. 11 and 12 in the Finnish Criminal Procedure Act.

${ }^{9}$ See also Pesonen (2011), p. 72.
} 
similar legal cultures ${ }^{10}$ and even a common history, they offer a fruitful context to discuss the opportunities and obstacles when adopting legal transplants and, in this case, considering whether plea bargaining can fit well into the Nordic legal culture or is likely to change it.

\section{Plea Bargaining in the East-Nordic Countries}

\subsection{Plea Bargaining in Finland}

In Finland, the plea bargaining system has existed since $2015 .{ }^{11}$ It is based on the confession and the consent of the victim. The aim is to save resources by having easier proceedings in these negotiated cases. Plea bargaining covers even the police investigation level. Investigation can be focused on the confessed crime only, whereas the other suspected but more unclear crimes are not investigated at all in the pleabargaining context. This can mean, for instance, bargaining even on an investigation and not only by way of proceedings and then sanction. ${ }^{12}$

The Finnish Criminal Investigation Act (805/2011), Chap. 3, Sect. 10a (672/2014) covers restriction of a criminal investigation on the basis of a confession. ${ }^{13}$

The decision of a prosecutor to waive of discontinue the criminal investigation and the commitment of the prosecutor to request a mitigated sentence are biding. They may be withdrawn only if the confession is withdrawn or in the view of new evidence in the case the decision or the commitment had been based on essentially incomplete or erroneous information. ${ }^{14}$ Plea bargaining may not be used for serious crimes. If the suspected offence is punishable by a sentence of imprisonment for more than six years or an important public or private interest requires that the criminal investigation be conducted. Additionally, there is a list of crimes which are not suitable for plea bargaining. ${ }^{15}$ Therefore, plea bargaining can be used only for minor crimes without a significant interest to prosecute.

The Finnish Criminal Procedure Act (689/1997), ${ }^{16}$ Chap. 5(b) covers proceedings on the basis of a plea of guilty (670/2014). There are some specific guarantees for legal relief in the plea-bargaining procedure. Namely, proceedings on the basis of a plea of guilty shall normally be held within 30 days of when the case becomes

\footnotetext{
${ }^{10}$ See Ervo (2021).

${ }^{11}$ On the legislative history and background, see Kananen-Ahjoharju (2012), pp. 28-45 and Linna (2012), pp. 126-131.

${ }^{12}$ Ervo (2014a), p. 105.

${ }^{13}$ The Act can be found as an English translation on the web: https:/www.finlex.fi/fi/laki/kaanno kset/2011/en20110805_20150736.pdf, accessed 28 June 2020.

${ }^{14}$ The Finnish Criminal Investigation Act, Chap. 3, Sect. 10a, Paragraph 4.

${ }^{15}$ The Finnish Criminal Investigation Act, Chap. 3, Sect. 10a, Paragraph 5.

${ }^{16}$ In its entirety, the Act can be found as an English translation on the web: https://www.finlex.fi/fi/ laki/kaannokset/1997/en19970689_20150733.pdf, accessed 28 June 2020.
} 
pending. In addition, the prosecutor and the defendant shall be present in person in the proceedings on the basis of a plea of guilty. Also, the injured party shall be reserved an opportunity to be present if, his or her claim is not being presented by the prosecutor. ${ }^{17}$ In the beginning of the proceedings on the basis of a plea of guilty, the prosecutor shall clarify the content of the proposal for judgment and the other circumstances connected with it, and present to the necessary extent the criminal investigation material dealing with the case. After that, the court shall inquire of the defendant, whether or not he or she continues to admit the offence and consents to the consideration of the case in this kind of simplified procedure. The court also checks whether or not he or she understands also in other respects the content and significance of the proposal for judgment. It is a duty of the court to seek to ensure that the proposal corresponds to the intent of the defendant. Then the court will reserve the defendant an opportunity to otherwise comment on the proposal for judgment and the criminal investigation material. After that, the court reserves the injured party an opportunity to comment on the proposal for judgment. Then other claims are heard and the parties are provided with an opportunity to present their closing statement. The court shall ensure that the case is dealt with appropriately and that irrelevant matters are not mixed into the case. The court shall use questions to eliminate ambiguities and deficiencies in the statements of the parties. ${ }^{18}$

Finally, the court shall issue a judgment according with the proposal for judgment if the defendant has made the admission and given the consent and no reasonable doubt remains regarding the voluntary and valid nature of the admission, taking into consideration also the criminal investigation material concerning the case. The court convicts in accordance with the proposal for judgment if there is otherwise no bar to acceptance of the proposal. If the court does not issue the judgment referred above, the case is withdrawn. If the case is dismissed without considering the merits, statements by the defendant that have been given in connection with the plea bargaining, may not be used as evidence in a criminal case. ${ }^{19}$

Because in Finland plea bargaining covers even the police investigation level as described above, investigation can then be focused on the confessed crime only, whereas the other suspected but more unclear crimes are not investigated at all in the plea bargaining context. By that mean, it is allowed to bargain also on an investigation and not only by way of proceedings and then sanction. However, fact bargaining is not allowed. By following the plea bargaining rules, the suspect may by bargaining 'choose' the crimes which will be investigated. Later on, there will be simplified proceedings. Also the sanctions which are used are milder than in normal cases. In the Finnish model, the state get benefits in the form of resource savings, and the accused get benefits in the form of limited police investigations, simplified procedures and milder sanctions. ${ }^{20}$

\footnotetext{
${ }^{17}$ The Finnish Criminal Procedure Act, Chap. 5(b), Sect. 2.

${ }^{18}$ The Finnish Criminal Procedure Act, Chap. 5(b), Sect. 3.

${ }^{19}$ The Finnish Criminal Procedure Act, Chap. 5(b), Sects. 4 and 5.

${ }^{20}$ Ervo (2014a), p. 105. On more detailed presentation of the plea bargaining in Finland, see Illman (2015), pp. 142-162.
} 


\subsection{The Crown Witnesses in Sweden}

When plea bargaining was suggested for Finland, legislators pointed out as benefits the efficiency and the appropriate allocation of resources to simplify the criminal proceedings. What was extremely interesting was that, at the same time, the Swedish legislature rejected the plea bargaining without any deeper discussion. It was simply stated that it did not fit into the Swedish system. ${ }^{21}$ It is very seldom that the EastNordic legislators have such different perspectives. As I have explained elsewhere, ${ }^{22}$ the Nordic legislators collaborate very much, and Swedish and Finnish legal reforms in particular often follow each other. Normally, Sweden is a role model that Finland follows, especially if the Swedish experience has been positive. In particular, the reforms in procedural law have traditionally followed the Swedish example. Therefore, this novelty, which is a legal transplant and quite a big step from civil law towards common law, ${ }^{23}$ is an exception in the East-Nordic legislative culture, which otherwise is very collaborative. ${ }^{24}$

Even if normal plea bargaining was rejected in Sweden, the use of crown witnesses, ${ }^{25}$ which is can be seen as one variant of plea bargaining, is currently debated in Sweden, and investigations are being made to determine whether this system should be adopted in Sweden. A crown witness is a defendant who receives mitigation of his or her sentence because he or she has participated or assisted in the investigation of someone else's crime. Mitigation is currently not included in the Swedish equitable grounds. The question of crown witnesses has already arisen several times in the Swedish political debate. In January 2019, the Prime Minister of Sweden announced that further inquiry regarding crown witnesses should be made. ${ }^{26}$ The next step was taken in December 2020, when the government introduced its so-called 34-point program, which includes efforts to combat gang crime. The possibility of using crown witnesses is mentioned in the program. It should be investigated whether crown witnesses could be a solution in this fight and whether the system could be adopted to Sweden. The deadline for that report is in May $2021 .{ }^{27}$ It is thus currently unknown whether the Swedish development in this question will follow the Finnish model. In Finland, plea-bargaining was also previously considered to be something negative that did not fit into the Finnish court culture. ${ }^{28}$ Changes in the

\footnotetext{
${ }^{21}$ Ervo (2014a), p. 109 and Government Bill (Finland) 58/2013.

${ }^{22}$ Ervo (2021).

${ }^{23}$ See Oikarinen (2008), pp. 11-53 and (2012), pp. 754-759, Pesonen (2011), p. 72 and Vilkko (2011), p. 40.

${ }^{24}$ See Ervo (2021).

${ }^{25}$ For more about crown witnesses as one version of plea bargaining, see Lauri (2010), pp. 30-35.

${ }^{26}$ Bentelius (2019), p. 1.

${ }^{27}$ https://www.regeringen.se/regeringens-politik/ett-tryggare-sverige/34-punktsprogrammet-regeri ngens-atgarder-mot-gangkriminaliteten/\#bryt_tystnadskulturen, accessed 12 February 2021.

${ }^{28}$ Linna (2010), pp. 227-235, Kananen-Ahjoharju (2012), pp. 46-81, Loiva (2008), pp. 73-81, 90, Oikarinen (2012), pp. 754-759 and Pesonen (2011), p. 43-57. Also, the relation between the right
} 
paradigm caused the way of thinking to change, and plea bargaining became more acceptable over time. ${ }^{29}$

According to the Swedish inquires, the attitude toward crown witnesses has been predominantly negative. Additionally, the adoption of crown witnesses in the Swedish legal tradition has resulted in criticism in literature. Based on the named empirical studies, even if the crown witness system is economically efficient, there is no place in the Swedish legal system for it. Even this aspect of economic efficiency is challenged in the inquiries by saying that there is no scientifically proven rise in efficiency due to such a system. ${ }^{30}$ Based on this background in attitudes, it will be exciting to see, if the system finally is adopted into the Swedish legislation or not.

However, in the Supreme Court case NJA 2009 p. 599, the court admitted mitigation for persons who, as a consequence of the fact that they named accomplices, would have to live their lives under serious threat. By doing so, the court indirectly opened up to the possibility of applying the system of crown witnesses in Swedish law through the case law. ${ }^{31}$ Still, this possibility to open new chances to act in the case law has not been found to be widely applicable, and, according to the Swedish legal tradition, it is the parliament as a legislator that should react and legislate on the possibility to make such a change. As I have explained elsewhere, ${ }^{32}$ these type of very creative solutions in the form of precedents to create new rules to meet new demands do not traditionally fit into the Swedish court culture.

\section{From Fairness Towards Feelings}

\subsection{From Sollen to Sein}

The traditional German concepts of 'sein' and 'sollen' have become closer to one another in terms of procedural fairness. Even if normative fairness and procedural justice from that point of view are based, for instance, on article 6 of the ECHR and other norms (sollen), the factual situation and the real feelings (sein) of the parties nowadays have much significance in the quality control of fairness. In this shift, the role of parties has changed from being subservient towards clients. ${ }^{33}$

Traditionally, it has been stressed that these concepts must be separated, and it has not been permissible to draw legally valid conclusions from sein, as only sollen has been decisive. In the contemporary paradigm, this distinction has been softened,

\footnotetext{
not to incriminate oneself and the plea bargaining system have been found to be problematic and is discussed in detail. Linna (2010), pp. 236-254 and Ridha (2014), p. 34.

${ }^{29}$ Oikarainen (2012), pp. 744-747 and Vilkko (2011), pp. 40-46.

${ }^{30}$ Bentelius (2019), p. 1 .

${ }^{31}$ See Bentelius (2019), where the case has been widely commented upon.

${ }^{32}$ Ervo (2021).

${ }^{33}$ Ervo (2014a), p. 101.
} 
and the concepts are-by many scholars—-nowadays regarded as more parallel than opposing. ${ }^{34}$

As described above, the aim of truth finding is disappearing. Instead, the way to the result should be fair, and the parties should be satisfied, indicating sein. The ingredients for this satisfaction need to be scooped from sein. The highly-valued sollen has lost its significance, whereas the instrumental way of thinking, as well as reality-based fairness, strongly affecting the court culture in addition to strengthening the use of 'sein' as a source, partly in decision making but especially in designing the way to it. ${ }^{35}$

This change is a strong piece of evidence on the change of the paradigm in the contemporary criminal proceedings. ${ }^{36}$

\subsection{Perceived Procedural Justice}

There has also been a change from the normative procedural justice towards a perceived procedural justice, which means that it is not sufficient that proceedings fulfill the requirements of normative procedural justice but that parties and other actors, like witnesses and experts as well as all actors involved in proceedings, should subjectively feel that the procedure was fair. This aspect of justice has been stressed by many scholars in the contemporary literature since 1990 's. ${ }^{37}$

According to that paradigm, the most important function in the adjudication is that the contextual decisions, with which the parties are satisfied, are produced through fair proceedings. In achieving these aims, the communication and interaction of judges and parties are the most important tools. ${ }^{38}$

\section{From Truth Finding Towards Negotiations}

Truth finding is no longer trendy. It is old-fashioned. Traditionally, the aim of procedure has been to find out the material truth. ${ }^{39}$ According to the earlier Chap. 17, Sect. 2 (571/1948) in the Finnish Code of Judicial Procedure, it was stated that 'after having carefully evaluated all the facts that have been presented, the court shall decide

\footnotetext{
${ }^{34}$ Ervasti (1998), p. 377, Ervo (2016), p. 280, Ervo (2005), p. 83, Lappi-Seppälä (1997), p. 201; Niemi (1996), p. 128, Searle (1988), p. 175, 1988 and Ukkonen (2013), p. 28.

${ }^{35}$ See Ervo (2005), p. 83 and Ervo (2016), p. 280.

${ }^{36}$ See also Ervo (2013b), pp. 51-71 and Ervo (2016), pp. 290-291.

${ }^{37}$ Ervasti (2004), p. 168; Haavisto (2002), p. 20, Laukkanen (1995), p. 214, Takala (1998), pp. 3-5, Tala (2002), Tyler (1990), p. 94 and Virolainen and Martikainen (2003), p. 5.

${ }^{38}$ Ervasti (2004), p. 168, Ervo (2014a), p. 101, Haavisto (2002), p. 20, Laukkanen (1995), p. 214, Jukka-Pekka Takala (1998), pp. 3-5, Tala (2002), pp. 21-23, Tyler (1990), p. 94, Virolainen and Martikainen (2003), p. 5.

${ }^{39}$ See, e.g., Tolvanen (2003), p. 1016 and (2006), p. 1329.
} 
what is to be regarded as the truth in the case.' This had been interpreted to refer to the material truth as an aim. In 2015, this Chap. 17 was reformed and now Sect. 3, which covers criminal cases, is as follows (12.6.2015/732):

In a criminal case, the plaintiff shall prove the circumstances on which his or her request for punishment is based. A judgment of guilty may be made only on the condition that there is no reasonable doubt regarding the guilt of the defendant.

This amendment came into force on 1 Jan 2016. After the reform, Chap. 17, Sect. 2, which covers civil cases, is as follows:

In a civil case, the party shall prove the circumstances on which his or her claim or objection is based, The wording used here is 'shall prove'. This can refer to a preponderance of evidence when a $51 \%$ probability is enough to win the case. ${ }^{40}$ Therefore, there is quite a lot of space for uncertainty. The advantage in the preponderance of evidence is a better chance to decide the case on its material bases-in other words, according to the substantive law. Namely, if the decision is 'not proven', the decision is based on the procedural law and the case is left as open what the material basis is concerned. $^{41}$

The above-cited wording of Sect. 2 in Chap. 17 covered both civil and criminal cases. As already stated, it was interpreted to refer to the material truth as an aim despite the fact that concrete decisions have always been based on the procedural truth and there have been many restrictions in the law of evidence in truth finding. Still, the material truth as an idealistic aim was seen to be important and to correspond with the contemporary values earlier before the reform, whereas this idealism has today lost its position, and the majority of scholars seem to think that it is not worth mentioning; often, it even causes clear resistance when discussed. ${ }^{42}$ Truth finding has lost its fascinating value as an idealistic goal, and daily life realism has replaced it.

Often, truth finding is even found to be something illegal or totalitarian. In the modern society, it has been linked with overly strong police power, lack of human rights, torture and so on-with something, which is anything else but idealistic, ${ }^{43}$ whereas in olden times the truth was something positive, the opposite of the false or lies. It was found to be fair as such, whereas today it is seen as a risk to a fair trial. This change described above, verifies the change in the way of thinking. The concept of the truth is interpreted in a different way, which indicates the changed values in the court culture. ${ }^{44}$

In Sweden, this has been the case before, and both the aim and the result in the proceedings have been based on the procedural truth only. According to the Swedish Code for Judicial Procedure, Chap. 35, Sect. 1:

The court shall determine what has been proved in the case after conscientious evaluating everything that has occurred in accordance with the dictates of its conscience.

\footnotetext{
${ }^{40}$ HE 46/2014 p. 46 and Saranpää (2010), p. 177.

${ }^{41}$ Saranpää (2010), pp. 260-264.

${ }^{42}$ See, e.g., Ervo 2012, pp. 1-16.

${ }^{43}$ Lehtimaja (1981), pp. 170-174 was already making such observations in the 1980s, and a similar way of thinking seems to have increased since them among scholars. Tolvanen (2003), and (2006).

${ }^{44}$ See, e.g., Tolvanen (2003), p. 1016 and Tolvanen (2006), p. 1329.
} 
If we look at history, the circle-described above-seems to be closed. In the past, the power to sanction belonged to the village communities. In addition, the family and relatives played a significant role in 'criminal procedure', which was based on the aim to find the public peace again and to avoid the spiral of revenge. The significance of the truth became more important only later, when the central power started to develop and the power to punish was moved to the state. In Sweden (of which Finland was a part at that time), the private settling of crimes was finally forbidden in 1540. By that royal act, the criminal proceedings were moved to the state monopoly. ${ }^{45}$ Today, it looks as if we are returning to these earlier times and 'ancient venues' by increasing the private decision-making power not only in civil proceedings but also in criminal procedure. ${ }^{46}$ The state is giving back its power to decide. By doing so, the meaning of truth finding is losing significance. The reason for this change seems to be related to the state economy. The lack of interest in having a monopoly in adjudication results in decreasing possibilities to fund all public sectors. However, at the same time, values in the society are changing. It seems no longer to be important to have a strong, powerful and power monopolizing state; instead, individualism and the ability to gain more space to disposee one's own business is more important than being an obedient servant. ${ }^{47}$

Conflict resolution has been a current trend in civil proceedings for decades. Now, it even affects criminal proceedings. Even in the context of criminal proceedings, the parties should be satisfied, and the conflict between them should be solved by legitimate means and in a comprehensive way. ${ }^{48}$ For instance, Tolvanen describes the contemporary criminal proceedings be noting that the first step is to qualify the current conflict, and then the parties try to prove their views to be correct. After this procedure, the result will be legitimate despite the facts of what really happened in the case. ${ }^{49}$

Courts are no longer state organs that use the sovereign's power to punish; instead, they are more of an independent body, to which the most important tasks belong to protect the fundamental rights of citizens. ${ }^{50}$ Even the realisation of criminal responsibility can mean that the conflict is just solved. The conflict can be solved by the parties' friendly settlement. By doing so, the material truth in the case will be disregarded. ${ }^{51}$ Still, in criminal cases, there is always also the public interest to consider. However, the common factors in both civil and criminal procedures today are communication, interaction, cooperation and fair trial as the most important aims. $^{52}$

\footnotetext{
${ }^{45}$ Ervo (2014b), pp. 386-390, Letto-Vanamo (1995), pp. 85-101 and Nousiainen (1993), pp. 319320.

${ }^{46}$ Vilkko (2011), pp. 43-46.

${ }^{47}$ See Ervo (2014a), pp. 386-391 and pp. 392-394.

${ }^{48}$ Tolvanen (2003), p. 1016 and Tolvanen (2006), p. 1329.

${ }^{49}$ Tolvanen (2003), p. 1016 and Tolvanen (2006), p. 1329.

${ }^{50}$ Tolvanen (2003), p. 1027.

${ }^{51}$ Tolvanen (2003), p. 1027.

${ }^{52}$ Tolvanen (2006), p. 1343.
} 
According to this conflict resolution function, the most important values in criminal procedure are that the parties are satisfied with the result and that the procedure is effective, cost-effective and functional. The material truth has lost its status, and even the procedural truth is developing in such a way that the parties may be permitted to dispose on it. By doing so, it is possible to start to talk about the negotiated law as a result, not only in the civil cases but also partly in the criminal proceedings. This is a fundamental change in the criminal procedural paradigm. ${ }^{53}$

The restorative justice and mediation in criminal cases are affecting in a similar way to the change of the paradigm. According to the restorative justice, conflicts can be seen as our property and resources. ${ }^{54}$ Based on restorative justice, the accused should face both the conflict and the victim. They should participate in the conflict resolution by themselves. It is not healthy to externalise the conflict to a too much serving court who does all for us. It should be totally the opposite; the criminal procedure should be based on the actor's personal participation, wherein they work for the solution of the case. Plea bargaining fits very well into this current picture of criminal proceedings and mirrors the contemporary values. ${ }^{55}$

\section{From the Right to be Heard to the Right to Decide}

The post-modern court culture in civil litigation is based on communication and interaction between the parties and the judge. Similar trends can be found even in criminal proceedings. ${ }^{56}$ There has been a big change from the adjudication, material truth and a substantively correct judgment towards the ideal of negotiated law and pragmatically acceptable compromise. The development has gone from the judicial power towards court service. ${ }^{57}$ The role of parties has been changed from the role as a subservient towards the role of clients. Additionally, party autonomy has been one of the key words especially in the Swedish procedural law discussion since 1990's. ${ }^{58}$

Plea bargaining can be seen as a procedural instrument where party autonomy covers procedural issues, or it can be seen as a substantive tool where the parties

\footnotetext{
${ }^{53}$ See, e.g., Ervo (2013a), pp. 47-55.

${ }^{54}$ Christie (1998), pp. 113-132.

${ }^{55}$ See Ervo (2012), pp. $13-15$ and Linna (2010). Illman took up the possibility that confessions based on plea bargaining do not necessarily correspond with the material truth. It is interesting that he still used the concept of the material truth in 2015 . He seemed to appreciate the material truth as an aim, while the possibility that confessions do not correspond was something negative. Illman (2015), p. 162. Also, Sahavirta has paid attention to the problem wherein false confessions do not correspond with the material truth. This can lead to problems in finding these types of false confessions binding. Therefore, plea bargaining can cause problems in res judicata. Sahavirta (2018), pp. 73-75.

${ }^{56}$ Ervo (2012), p. 15.

${ }^{57}$ Ervasti (2004), p. 433, Haavisto (2001), pp. 98-102 and Haavisto (2002), pp. 165-251, 260-262 and 287.

${ }^{58}$ Ervo (2009), pp. 21-41.
} 
agree on issues which belong to criminal law. In this distinction, the nature and scope of confession play the main role. The other important issue is the role of the parties, especially if the consent of the victim is needed, as well as how much the parties will attend to negotiations and decision making versus the prosecutor as a state representative primarily addressing the issue ex officio.

Especially in Sweden, the ultimate functions of proceedings have been discussed for decades. Conflict resolution has often been seen as a very important function, especially of civil proceedings, and with this development the perspective has been changed from external to internal and from a retrospective to a prospective point of view. $^{59}$

When discussing civil cases and the party autonomy concerning substantive matters in Sweden, Lindell has placed an emphasis on judicial relief in this context. According to him, the content of judicial relief is not only the idea to achieve a judgment, which has been achieved strictly according to substantive law. Rather, it also covers access to a certain procedure where consensus on the substantive legal matters exists. To reach this consensus, the agreed-upon result must not correspond with the substantive law only; rather, there is also space to find a suitable solution that to some extent opposes the law. The reason for this is public peace. Lindell thinks that the idea of confirming a settlement that covers the substantive law is not as radical or as impossible as it appears at first glance, and that it is possible to extend the party autonomy to cover fully even the substantial matters in the legislation. ${ }^{60}$

Concerning the criminal law, a similar context is plea bargaining, where the parties partly gain the power to decide the substantive - that is, criminal-law in the way which binds courts. Therefore, the role of courts is radically changing. It is seen clearly to be that of a client's conflict solver and not that of a state adjudicator that decides the case in the name of society and follow the law. Still, plea bargaining has often been seen as a technical instrument only, and its links to party autonomy as well as an understanding of substantive criminal law have not been addressed. The direct reason for this development may be the current governmental lack of resources, but the change cannot be made without accepting fundamental changes in the understanding of the criminal law and the criminal procedural law. These changes in the fundamental basis necessitate corresponding societal values to be valid and followed. If this adoption of very new instruments like plea bargaining works well in practice, it is at the same time a proof of the existence of new societal values.

\section{Conclusions}

Plea bargaining, written proceedings and procedure in absentia are contemporary, if not new, at least East-Nordic trends, which have been adopted or widened recently.

\footnotetext{
${ }^{59}$ Ervasti (2002), pp. 56-62, Leppänen (1998), pp. 32-41, Lindell (2003), pp. 82-101, Lindblom (2000), pp.46-58 and Virolainen (1995), pp. 80-89.

${ }^{60}$ Lindell (1988), p. 68.
} 
Theoretically, they are based on an agreement between the state authorities (a prosecutor or a judge and a suspected/accused).

Not only in civil procedure but also in criminal proceedings, the law can be seen as a negotiable compromise, not only between the victim and the accused but also between the state authorities and the parties. This is true especially in plea bargaining or when choosing the written procedure or the procedure in absentia.

Plea bargaining, written proceedings and procedure in absentia are concrete tools to realise the new paradigm and its elements, which includes conflict resolution, restorative justice, party autonomy and procedural truth. The use of these tools entails a new way of thinking and a substantial change in values.

However, the change is probably not totally controlled but at least partly accidental. The goal and need to put the state economy into balance affects the paradigm in a similar way. Still, due to the almost total lack of protests or wide scientific discussions, not to mention revolutions, the change seems to correspond with the current societal values. Therefore, it is not only about saving money and a budget-based way of thinking but also a change in a paradigm based on the surrounding new societal values.

The above described phenomena are more apparent in countries that have had a greater need to balance their budgets like Finland, compared with Sweden, which normally has a quite stable economy.

When plea bargaining was suggested for Finland, legislator pointed out the efficiency and the appropriate allocation of resources to simplify the criminal proceedings. At the same time, Swedish legislators rejected the plea bargaining without any deeper discussion beyond mentioning that it did not fit into the Swedish system.

However, Sweden has now started a similar discussion on crown witnesses to tackle organised crime. The system of planned crown witnesses is similar to plea bargaining, but the goal with this amendment is not the same. In Sweden, the purpose is to better address the war on organised crime, not to benefit the state economy or simplify proceedings.

In this sense, the societies and needs in the East-Nordic neighboring countries vary. In Finland, organised crime has not (yet) been as large a problem as it is in contemporary Sweden. However, the state economy has been in deep crisis in Finland, whereas Sweden's economy is more stable. The changes are leading to similar results, but the reasons seem to be different. Still, in both countries the general audience as well as scholars seem mainly to accept the changes and do not protest very much. Therefore, the prevalent values in those societies seem to correspond with each other. They also differ from the earlier criminal procedural values. The change in the criminal procedural paradigm seems to be reality in both contemporary East-Nordic societies.

Based on the discussion above, it is the author's opinion that the criminal process has moved towards party autonomy. Several examples that indicate this change has been identified in this chapter. The role of parties, their decision power and the significance of the 'atonement' are increasing in value, whereas the state's monopolistic penal authority is losing its significance. The big shift is in moving away from the material truth and the penal authority towards a societal solution to the conflict 
where the parties are in focus. The state is blessing this change because it corresponds with its economic aims. The paradigm change seems to be motivated not only by the changing societal values, which legislation always needs to mirror to be acceptable in a democracy, but also from the economic crisis and resulting unstable state economy in many European countries. This is an effective combination to put new theories and values into practice.

\section{References}

Bentelius H (2019) Passar ett kronvittnessystem i svensk rättsordning? En kritisk diskussion kring kronvittnen i svensk rätt. University of Lund, Lund

Christie N (1998) Konflikt Som Eiendom. Tidskrift for Rettvitenskap 90:113-132

Ervasti K (1998) Eräitä näkökohtia empiirisen tiedon hyväksikäyttämisestä oikeustieteessä. Lakimies 3:364-388

Ervasti K (2002) Lainkäytön funktiot. Lakimies 1:47-72

Ervasti K (2004) Käräjäoikeuksien sovintomenettely: empiirinen tutkimus sovinnon edistämisestä riitaprosessissa. Oikeuspoliittinen tutkimuslaitos, Helsinki

Ervo L (2005) Oikeudenmukainen oikeudenkäynti. Werner Söderström Osakeyhtiö, Helsinki

Ervo L (2009) Party autonomy and access to justice. In: Jokela A et al (eds) Europeanization of procedural law and the new challenges to fair trial. Europa Law Publishing, Groningen, pp 21-41

Ervo L (2012) Tie totuuteen. In: Hyttinen T (ed) Rikoksesta rangaistukseen: Juhlajulkaisu Pekka Viljanen 1952-26/8-2012. Turun yliopisto, Turku, pp 1-16

Ervo L (2013a) Changing civil proceedings: court service or state economy? In: Nekrošius V (ed) Recent trends in economy and efficiency of civil procedure. Vilnius University Press, Vilnius, pp $51-71$

Ervo L (2013b) Öiglase kohtupidamise väljavaated kriminaalasjades: tulevikuvisiooniid ja praegune olukord Skandinaavias ja Europas. Juridica 1:47-55

Ervo L (2014a) Nordic court culture in progress: historical and futuristic perspectives. In: Ervo L, Nylund A (eds) The Future of civil litigation: access to courts and court-annexed mediation in the Nordic countries. Springer, Cham, pp 383-407

Ervo L (2014b) Plea bargaining as an example of the recent changes in the Finnish criminal procedural paradigm. Baltic J Law Politics 1:97-112

Ervo L (2016) Facing people through language use: linguistic tools to make proceedings fair. Int J Legal Discourse 2:277-293

Ervo L (2021) Culture and mentality in East-Nordic courts. In: Ervo L et al (eds) Rethinking Nordic courts. Springer, Cham

Haavisto V (2001) Sovinnot: ikkuna tuomioistuintyön muutokseen. In: Pohjonen S (ed) Sovittelu ja muut vaihtoehtoiset konfliktinratkaisujärjestelmät. Werner Söderström Osakeyhtiö, Helsinki, pp 89-119

Haavisto V (2002) Court work in transition: an activity-theoretical study of changing work practices in a Finnish district court. University of Helsinki, Helsinki

Illman M (2015) Plea bargaining enligt finskt rätt. Tidskrift utgiven av Juridiska Föreningen i Finland 2:142-162

Kananen-Ahtoharju M (2012) Syytteistä sopiminen osaksi Suomen rikosrprosessia? Lainvalmisteluprosessin analysointi \& oikeusturvaongelmien jäsentäminen vastaajan näkökulmasta. Pro gradu -thesis May 2012 University of Helsinki, Faculty of Law. Published in Edilex 22.8.2012 www.edilex.fi/lakikirjasto/9011 
Lappi-Seppälä T (1997) Rikosoikeustutkimus, kriminaalipoliittinen orientaatio - ja metodi. In: Häyhä J (ed) Minun metodini. Werner Söderström Osakeyhtiö, Helsinki, pp 189-218

Laukkanen S (1995) Tuomarin rooli. Suomalainen Lakimiesyhdistys, Helsinki

Lehtimaja L (1981) Aineellinen totuus ja järkevä epäilys. Lakimies 170-174

Lauri A (2010) Kruununtodistajajärjestelmän ja sitä muistuttavien piirteiden soveltuminen suomalaiseen rikosprosessiin. Turun yliopisto, Turku

Leppänen T (1998) Riita-asiain valmistelu todistusaineiston osalta. Suomalainen Lakimiesyhdistys, Helsinki

Letto-Vanamo P (1995) Käräjäyhteisön oikeus. Oikeudenkäyttö Ruotsi-Suomessa ennen valtiollisen riidanratkaisun vakiintumista. Helsingin yliopisto, rikos-ja prosessioikeuden sekä oikeuden yleistieteiden laitos, Helsinki

Lindblom PH (2000) Processens funktioner: en resa i gränslandet. In: Lindblom PH (ed) Progressiv process: spridda uppsatser om domstolsprocessen och samhällsutvecklingen. Iustus, Uppsala, pp 593-632

Lindell B (1988) Partsautonomins gränser. Iustus, Uppsala

Lindell B (2003) Civilprocessen. Iustus, Uppsala

Linna T (2010) Puntarissa plea bargaining: vastassa oikeusturva ja itsekriminointisuoja. Oikeustiede - Jurisprudentia XLIII 43:189-262

Linna T (2012) Rikosvastuun huojennus: suomalainen plea bargaining hakee muotoaan. In: Hyttinen T (ed) Rikoksesta rangaistukseen. Juhlajulkaisu Pekka Viljanen 1952 - 26/8-2012. Turun yliopisto, Turku, pp 117-134

Määttä P (2013) Rikosasian joutuisa käsittely: perusoikeus ja tuomarin velvollisuus. Lakimiesliiton kustannus, Helsinki

Niemi M (1996) Päämäärien valtakunta. Konventionaalinen analyysi lainopillisen tiedon edellytyksistä ja oikeusjärjestelmän perusteista. Suomalainen Lakimiesyhdistys, Helsinki

Nousiainen K (1993) Prosessin herruus. Suomalainen Lakimiesyhdistys, Vammala

Oikarainen J (2012) Syyteneuvottelu ja tunnustamisoikeudenkäynti oikeuspoliittisena kysymyksenä - uhka vai mahdollisuus? Lakimies 5:742-763

Pesonen AE (2011) Tunnustaminen ja syytteestä sopiminen osaksi suomalaista rikosprosessia: käyttökelpoinen lisä keinovalikoimaan vai kyseenalaista kaupankäyntiä? Oikeuspoliittista keskustelua tunnustamisen muuttuvasta merkityksestä. Pro gradu - thesis February 2011 Eximia cum laude approbatur, University of Turku, Faculty of Law. Published in Edilex 5.9.2011 https://www.edi lex.fi/lakikirjasto/8044

Ridha S (2014) Plea bargaining suhteessa rikoksesta syytetyn itsekriminointisuojaan. Published in Edilex 23.12.2014 www.edilex.fi/acta_legis_turkuensia/14602. Published earlier in: Acta Legis Turkuensia 2014 Turun yliopiston Oikeustieteen Ylioppilaiden Yhdistys Lex ry

Sahavirta A (2018) Luottamuksella lopullisuuteen? Oikeusvoiman vaikutukset syyteneuvottelumenettelyssä. Itä-Suomen yliopisto, Kuopio

Saranpää T (2010) Näyttöenemmyysperiaate riita-asiassa. Suomalainen Lakimiesyhdistys, Vammala

Searle JR (1988) Speech acts. An essay in the philosophy of language. Cambridge University Press, Cambridge

Takala JP (1998) Moraalitunteet rikosten sovittelussa. Oikeuspoliittinen tutkimuslaitos, Helsinki

Tala J (2002) Luottamus tuomioistuimiin: mitä se on ja tarvitaanko sitä lisää? Lakimies 1:3-33

Tolvanen M (2003) Asianosaisten määräämistoimista rikosprosessissa. Defensor Legis 6:10091027

Tolvanen M (2006) Asianosaisten ja tuomioistuimen roolit todistelussa. Lakimies 7-8:1325-1343

Tyler TR (1990) Why people obey the law? Yale University Press, New Haven

Ukkonen IT (2013) Hyveen ja yhteisön mahdollisuus modernissa oikeudessa. University of Helsinki, Helsinki

Vilkko N (2011) Plea bargain-menettely Suomessa. Bookwell Oy, Vaajakoski 
Virolainen J (1995) Lainkäyttö: oikeudenkäynnin perusteet ja lainkäyttöelimet siviili-ja rikosprosessissa. Lakimiesliiton kustannus, Helsinki

Virolainen J, Martikainen P (2003) Pro et contra: tuomion perustelemisen keskeisiä kysymyksiä. Talentum, Helsinki

Open Access This chapter is licensed under the terms of the Creative Commons Attribution 4.0 International License (http://creativecommons.org/licenses/by/4.0/), which permits use, sharing, adaptation, distribution and reproduction in any medium or format, as long as you give appropriate credit to the original author(s) and the source, provide a link to the Creative Commons license and indicate if changes were made.

The images or other third party material in this chapter are included in the chapter's Creative Commons license, unless indicated otherwise in a credit line to the material. If material is not included in the chapter's Creative Commons license and your intended use is not permitted by statutory regulation or exceeds the permitted use, you will need to obtain permission directly from the copyright holder. 